https://doi.org/10.5800/GT-2017-8-3-0253

\title{
LITHIUM ISOTOPIC CONSTRAINTS ON THE ORIGIN OF I- AND A-TYPE GRANITES FROM EAST JUNGGAR (NW CHINA) OF THE CENTRAL ASIAN OROGENIC BELT: IMPLICATIONS FOR LI ISOTOPIC FRACTIONATION DURING CRUSTAL ANATEXIS
}

\author{
Bin Chen', Keke Sun², Chao Huang1, Hai-ou Gu1, 3 \\ ${ }^{1}$ School of Resources and Environmental Engineering, Hefei University of Technology, \\ Hefei 230009, China \\ ${ }^{2}$ School of Earth and Space Sciences, Peking University, Beijing 100871, China \\ ${ }^{3}$ School of Earth and Space Sciences, University of Science and Technology, Hefei 230026, China
}

For citation: Chen B., Sun K., Huang C., Gu H., 2017. Lithium isotopic constraints on the origin of I- and A-type granites from East Junggar (NW China) of the Central Asian Orogenic Belt: Implications for Li isotopic fractionation during crustal anatexis. Geodynamics \& Tectonophysics 8 (3), 429-430. doi:10.5800/GT-2017-8-3-0253.

Though Li isotope fractionation during mantle melting and differentiation of basaltic melts have been proved insignificant, Li isotopic systems during crustal processes remain unclear. To study this, we report combined petrological, $\mathrm{Nd}-\mathrm{Sr}$ and $\mathrm{Li}$ isotopic data for the late Paleozoic coexisting I- and A-type granites in the East Junggar orogen of the Central Asian Orogenic Belt. The granites were formed responding to underplating of mafic magmas in the lower crust in a postcollisional, extensional regime, and intruded into the Paleozoic foldbelts that formed due to extensive oceanic subduction-accretion processes.
The I-type granites have equally important calcic hornblende and biotite, and contain minor but widespread mafic microgranular enclaves (MME). They show chemistry typical of calc-alkaline granites, e.g., $\mathrm{SiO}_{2}=60-70 \%$ and $\mathrm{CaO}=1.9-5.0 \%$, and are characterized by MORB-like $\mathrm{Nd}-\mathrm{Sr}$ isotopes, with $\varepsilon_{\mathrm{Nd}}(\mathrm{t})=5.9-6.3$, and $\mathrm{I}_{\mathrm{Sr}}=0.70355-0.70446$, and the two figures for MMEs are $\sim+6.5$ and 0.70355-0.7041, respectively. These features, along with the textures and mineral chemistry, suggest the I-type granites formed mainly from partial melting of the deeply-buried Paleozoic metabasites, and subordinately from mixing of post- 
collisional mafic magma in the source. The younger alkaline granites include biotite- and hornblende A-types. The biotite A-types are characterized by the occurrence of annite (without hornblende), and the hornblende A-types by sodic hornblende (arfvedsonite) and scarce Fe-rich biotite. The two categories of A-type granites show high $\mathrm{SiO}_{2}$ (74-78 \%), very low $\mathrm{MgO}, \mathrm{CaO}$, $\mathrm{Al}_{2} \mathrm{O}_{3}, \mathrm{Ba}$ and $\mathrm{Sr}$, and have Nd isotopic compositions comparable to those of the I-types, but the biotite A-types show $\mathrm{Rb}, \mathrm{K}_{2} \mathrm{O}$ and $\mathrm{Li}$ higher than the hornblende A-types. These features suggest that the biotite A-types originated from melting of an equivalent to the I-type granites, controlled by biotite dehydration melting, and the hornblende A-types from re-melting of the granulitic residue after extraction of the biotite A-types controlled mainly by hornblende dehydration melting.

The I-type granites have $\mathrm{Li}=35-47 \mathrm{ppm}$ and $\delta^{7} \mathrm{Li}=+3.0 \sim+3.7 \%$, and the two figures for MME are $52-88 \mathrm{ppm}$ and $+1.4 \sim+2.2 \%$. The biotite A-type granites have Li (54-141 ppm) and $\delta^{7} \mathrm{Li}(+3.6 \sim+4.6 \% 0)$, which are significantly higher than the hornblende
A-types (50-61 ppm and $+2.6 \sim+3.5 \%$, respectively). Modeling using the Rayleigh dehydration melting model supports the formation of I-type granites by mixing of a metabasite-derived granitic melt with small amounts of mafic magma, and the inferred granite melt is predicted to have $\delta^{7} \mathrm{Li}=+5 \%$, suggesting a measurable $\mathrm{Li}$ isotopic fractionation during the melting of metabasites. Also, modeling suggests that melting of equivalent to the I-type granites can form a granite melt with $\mathrm{Li}=70-126 \mathrm{ppm}$ and $\delta^{7} \mathrm{Li}=+3.7 \sim+4.7 \%$, and re-melting of the granulitic residue at higher temperatures can yield a granite melt with $\mathrm{Li}=51-78 \mathrm{ppm}$ and $\delta^{7} \mathrm{Li}=+2.8 \sim+3.6 \%$, which are largely comparable to those of the biotite A-type and hornblende A-type granites, respectively. Our new data suggest that (1) crustal anatexis via dehydration melting of hydrous phases can produce small but notable $\mathrm{Li}$ isotopic fractionation, thus $\mathrm{Li}$ isotopes of granites cannot be used to directly reflect the source, and (2) A-type granites can be produced by dehydration melting of biotite- and/or hornblende-bearing I-type granites. 